\title{
Analisis Kualitas Geometri Mesin Bubut Maximat Super 11
}

\author{
Eko Indrawan $^{1 *}$, Yufrizal A ${ }^{1}$, Abdul Aziz ${ }^{1}$, Rifelino ${ }^{1}$, Muhammad Iqbal Tawakal ${ }^{1}$ \\ ${ }^{1}$ Jurusan Teknik Mesin, Fakultas Teknik, Universitas Negeri Padang \\ *Corresponding author, e-mail: ekoindrawan@,ft.unp.ac.id
}

\begin{abstract}
Abstrak - Penelitian ini bertujuan sejauh mana tingkat kepresisian dari mesin bubut maximat super 11 di Laboratorium Teknologi Produksi. Pengumpulan data dilakukan pengujian putaran (run out) spindle nose, pengujian ketirusan lubang spindle nose, pengujian kelurusan tailstock guideways terhadap gerakan eretan dan pengujian kebulatan terhadap benda kerja dalam pembubutan rata. Hasil penelitian pengujian putaran (run out) spindle nose masih dalam batas toleransi yang ditetapkan schlesinger standart $(0.01 \mathrm{~mm})$, pengujian ketirusan lubang spindle nose hampir secara keselurahan mesin sudah melewati batas penyimpangan yang diizinkan (posisi $A=0.01 \mathrm{~mm}$, posisi $B$ $=0.02 \mathrm{~mm}$ per $30 \mathrm{~mm}$ ), pengujian kelurusan lintasan semua mesin sudah melewati batas penyimpangan $(0.01 \mathrm{~mm}$ per $500 \mathrm{~mm})$ dan dicobakan untuk pembubutan rata pada benda kerja (spesimen) ditentukan untuk 2 mesin dengan penyimpangan terkecil (M17) dan terbesar (M20) dari keseluruhan mesin dan setelah diuji tingkat kebulatan dari kedua benda disimpulkan masih dalam batas toleransi yang diizinkan (0.015 mm per $120 \mathrm{~mm})$.
\end{abstract}

Kata Kunci : Maximat Super 11, Kualitas Geometri, Produk

\begin{abstract}
- this study looks at the extent of the precision of the super 11 maximat lathe in the Production Technology Laboratory. Data collection was carried out by spindle nose run-out testing, spindle nose hole sharpness testing, tailstock guide ways straightness testing for slack movements and roundness testing of work pieces in flat turning. The results obtained by testing the spindle nose run out are still within the tolerance limits set by Schlesinger standard $(0.01 \mathrm{~mm})$, the spindle nose hole test is almost entirely the engine has passed the permitted deviation limit (position $A=0.01 \mathrm{~mm}$, position $B=0.02 \mathrm{~mm}$ per $30 \mathrm{~mm}$ ) all tailstock guide ways have passed the deviation limit $(0.01 \mathrm{~mm}$ per $500 \mathrm{~mm})$ and are tested for flat turning on work pieces (specimens) determined for 2 machines with the smallest (M17) and biggest (M20) of the whole machine and after testing the roundness level of the two objects it was concluded to be within the permissible tolerance range $(0.015$ mm per $120 \mathrm{~mm}$ ).
\end{abstract}

Keywords : Maximat super 11, Quality of geometry, Product

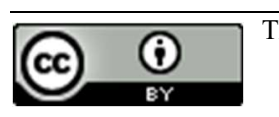

This is an open access article distributed under the Creative Commons 4.0 Attribution License

\section{Pendahuluan}

Mesin bubut merupakan salah satu jenis mesin proses produksi yang dipakai untuk membentuk benda kerja yang berbentuk silindris[1]. Alat potong (pahat) yang dipakai untuk membentuk benda kerja akan disayatkan pada benda kerja yang berputar[2].

Mesin perkakas merupakan penghasil sebagian besar produk industri logam yang mempergunakan proses pengerjaan tertentu. Maka ketelitian produk yang dibuat sangat tergantung pada kondisi mesin tersebut. Salah satu faktor yang berpengaruh adalah kondisi geometri mesin meliputi ketelitian permukaan referensi, ketelitian gerak linear, ketelitian putaran spindel, dan ketelitian gerak perpindahan. Mesin perkakas produksi adalah suatu alat yang berfungsi sebagai pembuat komponen atau macam benda kerja misalnya komponen pemesinan, perkakas untuk keperluan industri, benda untuk kebutuhan rumah tangga, dan benda lain yang merupakan hasil 
pengerjaan mesin perkakas. Kualitas permukaan hasil pembubutan dapat dipengaruhi oleh beberapa faktor seperti menentukan kecepatan putaran spindel, menentukan kecepatan potong (cutting speed), sudut potong[3]. Metrologi adalah ilmu pengukuran yang mempelajari jenis alat ukur keteknikan, metode pengukuran, kalibrasi dan akurasi di bidang industri[4].

Mesin perkakas khususnya Mesin Bubut Maximat Super 11 yang terdapat di Laboratorium Teknologi Produksi Jurusan Teknik Mesin Fakultas Teknik Universitas Negeri Padang telah dipakai dalam jangka waktu lama ( \pm 30 tahun). Tentu saja bagian-bagian yang bergesekan seperti: lintasan mesin, bantalan poros yang akan mengalami keausan.

Hal ini mempengaruhi ketelitian mesin tersebut, karena tidak pernahnya dilakukan Pengujian geometri pasti akan mengalami keausan pada berbagai komponennya sehingga menyebabkan terjadinya penyimpangan terhadap ketelitian semula. Besarnya penyimpangan itu tidak boleh melewati batas yang diijinkan. Besarnya penyimpangan yang terjadi dapat diketahui dari hasil pengujian ketelitian geometri menurut standar acuan dari Schlesinger standard serta standar ISO 230.

Jenis komponen yang dihasilkan oleh mesin perkakas pada prinsipnnya adalah komponen untuk keperluan perakitan dan tidak perlu dirakit. Untuk komponen yang dirakit atau disatukan dengan komponen yang lain, maka untuk mencapai: 1) ketelitian ukuran, 2) bentuk yang ideal, dan 3) dimensi lain dari komponen tersebut harus terpenuhi sesuai dengan kualitas yang diminta. Sehingga komponen tersebut kalau disetel atau dirakit, proses perakitannya tidak mengalami kesulitan, tidak memerlukan waktu banyak untuk mengadakan penyesuaian di antara komponen yang dirakit.

Jika demikian, maka mesin perkakas yang digunakan untuk mengerjakan komponen tersebut harus bisa memenuhi ketelitian atau kualitas yang diminta oleh komponen yang dikerjakan, dengan demikian ketelitian mesin perkakas (ketelitian geometri) dan harus betul-betul memenuhi standar yang sudah ditentukan. Jika tidak jelas mesin itu tidak akan bisa bekerja dengan teliti, sehingga hasilnyapun tidak sesuai dengan ketelitian yang diminta.

Demikian juga pada mesin perkakas yang telah dibongkar, pemasangan dan penyetelannya kembali paling tidak harus mendekati harga standart yang ada dalam pengetesan atau pengujian mesin perkakas. Secara kasar semua penyimpangan yang terjadi tidak boleh melebihi dari harga $0.02 \mathrm{~mm}$ sampai dengan $0.05 \mathrm{~mm}$ (dianggap sebagai pedoman jika si pekerja atau teknisi mesin perkakas tidak mempunyai test chart sesuai dengan mesin perkakas yang sedang diperbaiki).

Besarnya penyimpangan itu tidak boleh melewati batas diijinkan. Besarnya penyimpangan yang terjadi dapat diketahui dari hasil pengujian ketelitian geometri[5].

Mesin perkakas produksi adalah suatu alat yang berfungsi sebagai pembuat komponen atau macam benda kerja misalnya komponen pemesinan, perkakas untuk keperluan industri, benda untuk kebutuhan rumah tangga, dan benda lain yang merupakan hasil pengerjaan mesin perkakas. Mesin bubut adalah suatu jenis mesin perkakas produksi yang dalam proses kerjanya bergerak memutar benda kerja dan menggunakan mata potong pahat (tools) sebagai alat untuk menyayat benda kerja tersebut. Mesin bubut merupakan salah satu jenis mesin proses produksi yang dipakai untuk membentuk benda kerja yang berbentuk silindris.

Bagian utama mesin bubut adalah sumbu utama (main spindle), eretan (carriage), kepala lepas (tailstock), meja mesin (Bed), transporter dan sumbu pembawa. Mesin perkakas produksi adalah suatu alat yang berfungsi sebagai pembuat komponen atau macam-macam benda kerja misalnya komponen-komponen pemesinan, perkakas-perkakas untuk keperluan industri, benda-benda untuk kebutuhan rumah tangga, dan benda-benda lain yang merupakan hasil pengerjaan mesin perkakas [6].

\section{Standar Pengujian}

Benda kerja yang dihasilkan oleh proses pemotongan tersebut memiliki kualitas tertentu dan bila diketahui dari ketelitian dimensi, ketelitian bentuk serta kehalusan permukaan benda kerja tersebut. Salah satu faktor yang mempengaruhi ketelitian benda kerja adalah ketelitian mesin bubut yang dipergunakan dalam proses pemotongan benda kerja itu.

Ketelitian benda kerja yang dihasilkan oleh proses pemotongan tersebut tidak semata dipengaruhi oleh ketelitian geometri mesin bubut saja, tetapi masih ada pengaruh beberapa factor lain, antaranya:
a. Keadaan proses pemotongan
b. Temperatur lingkungan
c. Keadaan pahat
d. Pemasangan benda kerja pada pencekam
e. Gaya-gaya pemotongan 
Ketelitian geometri mesin perkakas yang langsung mempengaruhi kualitas benda kerja adalah:

a. Ketelitian permukaan referensi

b. Ketelitian gerak linier

c. Ketelitian putaran spindel

d. Ketelitian gerak pindah (displacement accuracy)

Agar kualitas produk dapat sesuai perancangannya, maka salah satu yang harus dipenuhi adalah ketelitian geometri yang memenuhi persyaratan sesuai dengan standar acuan baku sebagai referensinya. Di dalam kasus penelitian ini salah satu mesin produksi berupa mesin bubut Maximat Super 11 yang sudah lebih dari 30 tahun dipergunakan dan belum pernah diuji kembali ketelitian geometrinya. Dengan demikian kemungkinan sudah terjadi penyimpangan atau kesalahan geometri mesin tersebut yang akan menurunkan kualitas dari benda kerjanya. Sehingga tujuan penulisan ini adalah:

a. Untuk mengetahui apakah mesin bubut tersebut masih memenuhi standar atau memiliki tingkat ketelitian yang baik sesuai dengan standar acuannya, dimana dalam hal ini standar yang digunakan adalah standar Schlesinger (standar yang dibuat oleh Dr. Georg Schlesinger).

b. Untuk kegiatan pemeliharaan, dimana apabila memang penyimpangan yang terjadi pada mesin perkakas tidak memenuhi standar dapat direkondisi ulang.

Metode yang dipakai dalam pengujian ketelitian geometrik mesin bubut ini menggunakan metode pengujian langsung dengan alat uji yang sesuai dengan apa yang disyaratkan pada standar acuan dan dilaksanakan berdasarkan ketentuan prosedur pengujian. Secara umum metode pengujian ketelitian geometri mesin perkakas yang adalah berdasarkan standar ISO (International Organization for Standardization) pada pedoman ISO 230. Menurut ISO 230, ada dua macam pengujian ketelitian geometri dari mesin perkakas, yaitu:

1. Pengujian ketelitian dinamik (Pratical test)

Pengujian ini dilakukan dengan menggunakan benda kerja uji (test work pieces) yang dikerjakan dalam kondisi finishing (under finishing conditions).

2. Pengujian ketelitian statik (geometrical test) Pengujian ini dilakukan tanpa pembebanan dan mesin dalam keadaan tidak bekerja. Hal yang harus diuji adalah penyimpangan geometri dari setiap komponen gerak pindah relatif satu dengan yang lain.

\section{Pokok-pokok Pengujian Ketelitian Geometri Mesin Perkakas}

Pengujian goemetris mesin perkakas khususnya mesin bubut dimaksudkan untuk mengadakan pengujian terhadap dimensi-dimensi dan bentuk-bentuk serta posisi-posisi dari komponen mesin antara yang satu dengan yang lainnya, misalnya ketegaklurusan antara dua bidang, kesejajaran antara dua gerakan, kesejajaran antara dua bidang dan lain sebagainya. Ada beberapa konsep dasar dalam pengujian ketelitian geometris mesin perkakas, yaitu:

a. Kelurusan (straightness)

b. Kedataran (flatness)

c. Kesejajaran (paralellism)

d. Ketegaklurusan

e. Penyimpangan Rotasi

\section{Metode Penelitian}

Teknik pengumpulan data langsung berhadapan dengan mesin bubut yang di uji, alat yang digunakan dial indikator, mandrel uji/silinder refference, dan alat ukur lainnya bila dibutuhkan.

Teknik Analisis Data yang diambil dari pengujian ketelitian geometri mesin bubut yang terdiri dari:

\section{Pengujian Putaran (Run Out) Spindle Nose}

Pengujian putaran (run out) spindle nose terdiri dari 2 jenis yaitu: pengujian terhadap perbandingan kecepatan terendah $(55 \mathrm{rpm})$ dengan kecepatan tertinggi (2200 rpm) pada mesin. Lalu pengujian kebulatan pada penampang spindle dimana standar yang diizinkan menurut Schlesinger standard (0.01 $\mathrm{mm}$ ). alat ukur dan alat bantu yang digunakan adalah Dial Indikator $(\mu \mathrm{m})$, kertas pembagi kebulatan, dan tabel pencatat. Pengujiannya seperti gambar dibawah ini:

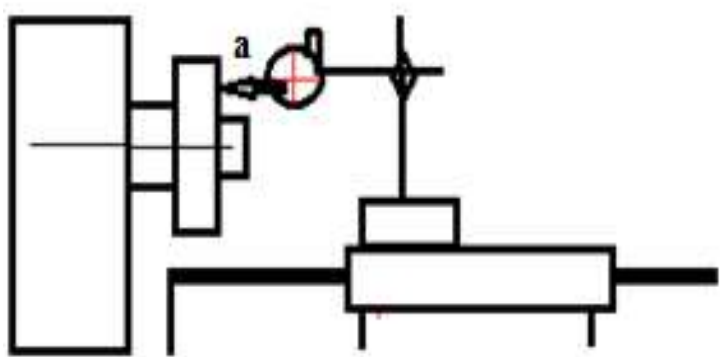

Gambar 1. Pengujian Putaran Spindle Nose (Posisi a dan b)

\section{Pengujian Ketirusan Lubang Spindle Nose}

Pengujian Ketirusan Lubang Spindle nose ini menggunakan mandrel uji/sillinder 
reference, dimana dalam pengujian ini. Ada 2 titik pengujian pada mandrel uji menurut prosedur pengujian menurut Schlesinger standard yaitu: (Posisi $A=0.01 \mathrm{~mm}$, Posisi $\mathrm{B}=0.02 \mathrm{~mm} / 300 \mathrm{~mm}$ ), dimana prosedur pengujiannya seperti gambar dibawah ini:

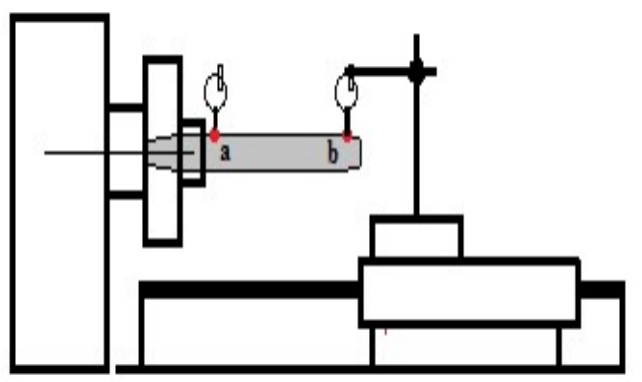

Gambar 2. Pengujian Ketirusan dari Lubang Spindle Nose

3. Pengujian Pembimbing jalan Kepala lepas (Tailstock Guideways) terhadap Gerakan Eretan (Carriage)

Pada pengujian Lintasan mesin dimaksudkan untuk menguji kelurusan dari bidang lintasan. Alat ukur yang digunakan Dial Indikator $(\mu \mathrm{m})$. Dimana standar penyimpangan yang diizinkan menurut shclesinger standar $(0.01 \mathrm{~mm} / 500 \mathrm{~mm})$. Prosedur pengujian seperti gambar dibawah ini:

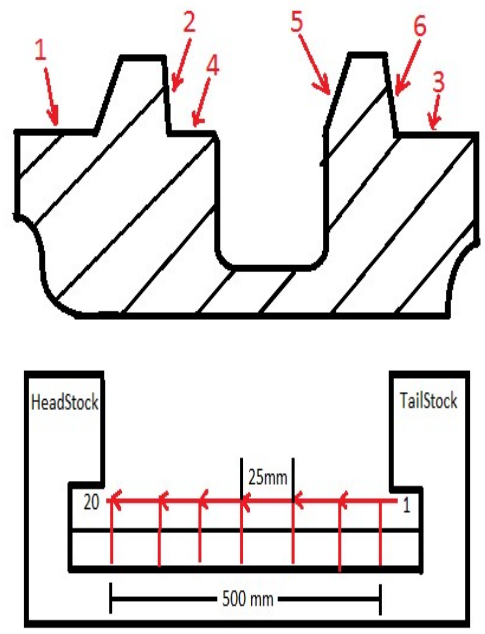

Gambar 3. Prosedur Posisi Pengujian Tailstock Guideways
III. Hasil dan Pembahasan

a. Pengujian Putaran (run out) pada Spindle Nose

Tabel 1. Pengujian Putaran (run out) pada Spindle Nose (bagian a)

\begin{tabular}{|c|c|c|c|c|}
\hline No. & $\begin{array}{c}\text { No. } \\
\text { Mesin }\end{array}$ & $\begin{array}{c}\mathbf{n} \\
\text { Minimum } \\
\text { (55 rpm) }\end{array}$ & $\begin{array}{c}\mathbf{n} \\
\text { Maximum } \\
\text { (2200 rpm) }\end{array}$ & $\begin{array}{c}\text { Standar } \\
\text { yang } \\
\text { diizinkan } \\
\text { (mm) }\end{array}$ \\
\hline 1 & M13 & 0.006 & 0.012 & $0.01 \mathrm{~mm}$ \\
2 & M14 & 0.008 & 0.015 & sda \\
3 & M17 & 0.004 & 0.08 & sda \\
4 & M18 & 0.006 & 0.011 & sda \\
5 & M19 & 0.006 & 0.012 & sda \\
6 & M20 & 0.009 & 0.018 & sda \\
\hline
\end{tabular}

Dari Tabel 1 dan 2 pada Pengujian dapat diambil kesimpulan bahwa:

1. Berdasarkan Pengujian Spindle Nose (bagian a dan b) di atas didapatkan ternyata dari 6 unit mesin yang diuji ternyata tidak ada satupun mesin yang menyimpang dari standar yang diizinkan $(0.01 \mathrm{~mm})$.

2. Secara umum dapat dikatakan semua mesin tidak ada yang menyimpang dari persentase rata-rata didapatkan kondisi baik dalam pengujian putaran (run out) Spindle Nose.

\section{b. Pengujian Ketirusan dari Lubang Spindle} Nose

Tabel 3 dapat diambil pada pengujian

Ketirusan dari Lubang Spindle Nose bahwa:

a. Penyimpangan toleransi yang paling rendah ada pada Mesin bubut (M17).

b. Penyimpangan toleransi yang paling tinggi ada pada Mesin bubut (M20).

Tabel 2. Pengujian putaran (run out) Spindle Nose (bagian b)

\begin{tabular}{|c|c|c|c|c|c|c|c|c|c|c|c|c|c|c|c|c|c|c|}
\hline No. & \multicolumn{10}{c|}{ Simpangan $(\boldsymbol{\mu m})$} & Rata-rata & mm \\
\cline { 2 - 16 } Mesin & $\mathbf{1}$ & $\mathbf{2}$ & $\mathbf{3}$ & $\mathbf{4}$ & $\mathbf{5}$ & $\mathbf{6}$ & $\mathbf{7}$ & $\mathbf{8}$ & $\mathbf{9}$ & $\mathbf{1 0}$ & $\mathbf{1 1}$ & $\mathbf{1 2}$ & $\mathbf{1 3}$ & $\mathbf{1 4}$ & $\mathbf{1 5}$ & $\mathbf{1 6}$ & & \\
\hline M13 & 0 & -2 & -2 & -4 & -5 & -4 & -4 & -4 & -5 & -5 & -5 & -4 & -3 & -3 & -3 & 0 & -3.3125 & $\mathbf{- 0 . 0 0 3 3}$ \\
M14 & 0 & -3 & -2 & -3 & -5 & -4 & -4 & -6 & -6 & -5 & -6 & -5 & -5 & -5 & -2 & 0 & -3.8125 & $\mathbf{- 0 . 0 0 3 8}$ \\
M17 & 0 & 0 & 0 & -2 & -2 & -2 & -3 & -3 & -3 & -2 & -2 & -2 & -2 & -2 & -1 & 0 & -1.625 & $\mathbf{- 0 . 0 0 1 6}$ \\
M18 & 0 & -3 & -2 & -3 & -3 & -4 & -2 & -2 & -3 & -3 & -3 & -5 & -5 & -4 & -2 & 0 & -2.75 & $\mathbf{- 0 . 0 0 2 8}$ \\
M19 & 0 & -3 & -4 & -4 & -5 & -4 & -4 & -3 & -4 & -5 & -6 & -4 & -4 & -4 & -2 & 0 & -3.5 & $\mathbf{- 0 . 0 0 3 5}$ \\
M20 & 0 & -3 & -4 & -5 & -5 & -5 & -5 & -4 & -4 & -4 & -6 & -8 & -8 & -5 & -3 & 0 & -4.3125 & $\mathbf{- 0 . 0 0 4 3}$ \\
\hline
\end{tabular}


Tabel 3. Pengujian Ketirusan dari lubang Spindle Nose

\begin{tabular}{|c|c|c|c|c|}
\hline No & \begin{tabular}{|l|} 
Kode \\
Mesin \\
\end{tabular} & $\begin{array}{c}\text { Penyimpangan } \\
\text { yang Dicapai }\end{array}$ & \begin{tabular}{|c|}
$\begin{array}{c}\text { Standar yang } \\
\text { Diizinkan }\end{array}$ \\
\end{tabular} & Penyimpangan \\
\hline \multirow[t]{2}{*}{1} & M13 & 0.02 & 0.01 & 0.01 \\
\hline & & 0.03 & $0.02 / 300 \mathrm{~mm}$ & 0.01 \\
\hline \multirow[t]{2}{*}{2} & M14 & 0.03 & & 0.02 \\
\hline & & 0.03 & sda & 0.01 \\
\hline \multirow[t]{2}{*}{3} & M17 & 0.02 & & 0.01 \\
\hline & & 0.02 & sda & - \\
\hline \multirow[t]{2}{*}{4} & M18 & 0.03 & & 0.02 \\
\hline & & 0.03 & sda & 0.01 \\
\hline \multirow[t]{2}{*}{5} & M19 & 0.03 & & 0.02 \\
\hline & & 0.03 & sda & 0.01 \\
\hline \multirow[t]{2}{*}{6} & M20 & 0.04 & & 0.03 \\
\hline & & 0.04 & sda & 0.02 \\
\hline
\end{tabular}

c. Pengujian Pembimbing jalan Kepala Lepas (Tailstock Guideways) terhadap gerakan Eretan (Carriage)

Tabel 4. Hasil Pengujian pada mesin bubut 1 (M13)

\begin{tabular}{|c|c|c|c|c|c|c|c|c|}
\hline \multirow{2}{*}{$\begin{array}{c}\text { Posisi } \\
\text { Pengujia } \\
n \\
(25 \mathrm{~mm})\end{array}$} & \multicolumn{8}{|c|}{ Simpangan ( $\mu \mathrm{m})$} \\
\hline & 1 & 2 & 3 & 4 & 5 & 6 & Rata-Rata & Mm \\
\hline 1 & 0 & 3 & -2 & -15 & -12 & -6 & -5.33 & -0.01 \\
\hline 2 & -2 & 3 & -18 & -25 & -30 & -14 & -14.33 & -0.01 \\
\hline 3 & -8 & -2 & -25 & -34 & -37 & -29 & -22.50 & -0.02 \\
\hline 4 & -16 & -10 & -29 & -44 & -43 & -40 & -30.33 & -0.03 \\
\hline 5 & -21 & -14 & -30 & -50 & -46 & -45 & -34.33 & -0.03 \\
\hline 6 & -21 & -22 & -30 & -49 & -47 & -45 & -35.67 & -0.04 \\
\hline 7 & -21 & -31 & -31 & -46 & -47 & -46 & -37.00 & -0.04 \\
\hline 8 & -29 & -32 & -33 & -42 & -47 & -40 & -37.17 & -0.04 \\
\hline 9 & -38 & -47 & -28 & -35 & -46 & -25 & -36.50 & -0.04 \\
\hline 10 & -47 & -47 & -18 & -24 & -47 & 0 & -30.50 & -0.03 \\
\hline 11 & -56 & -46 & -7 & -3 & -46 & 30 & -21.33 & -0.02 \\
\hline 12 & -58 & -27 & 24 & 22 & -40 & 60 & -3.17 & 0.00 \\
\hline 13 & -58 & -3 & 25 & 23 & -30 & 56 & 2.17 & 0.00 \\
\hline 14 & -46 & 15 & 34 & 25 & -29 & 40 & 6.50 & 0.01 \\
\hline 15 & -32 & 33 & 51 & 84 & -27 & -80 & 4.83 & 0.00 \\
\hline 16 & -26 & 38 & 42 & 85 & -28 & -80 & 5.17 & 0.01 \\
\hline 17 & -16 & 37 & 27 & 30 & -31 & 20 & 11.17 & 0.01 \\
\hline 18 & -16 & 47 & 5 & 46 & -46 & 25 & 10.17 & 0.01 \\
\hline 19 & -12 & 49 & -17 & 45 & -60 & 34 & 6.50 & 0.01 \\
\hline 20 & -12 & 50 & -39 & 50 & -76 & 41 & 2.33 & 0.00 \\
\hline
\end{tabular}

Tabel 4 pengujian di atas dapat diambil rata-rata bahwa:

a. Pembebanan terhadap lintasan Bed (guideways) terjadi pada titik bagian 3-11, dimana penyimpangan yang terjadi lebih dari penyimpangan yang diizinkan $(0,01 \mathrm{~mm})$, bila dihitung ada 8 titik bagian $(8 \times 25 \mathrm{~mm}=200$ $\mathrm{mm})$

b. Secara umum dapat dikatakan hampir separoh dari panjang lintasan $(200 \mathrm{~mm} / 500 \mathrm{~mm})$.
Tabel 5. Hasil Pengujian pada Mesin bubut 2 (M14)

\begin{tabular}{|c|c|c|c|c|c|c|c|c|}
\hline $\begin{array}{c}\text { Posisi } \\
\text { Pengujia } \\
\mathbf{n} \\
\mathbf{( 2 5} \mathbf{~ m m})\end{array}$ & $\mathbf{1}$ & $\mathbf{2}$ & $\mathbf{3}$ & $\mathbf{4}$ & $\mathbf{5}$ & $\mathbf{6}$ & Rata-Rata & $\mathbf{m m}$ \\
\hline $\mathbf{1}$ & -10 & -1 & -9 & -10 & -19 & -12 & -10.17 & -0.01 \\
\hline $\mathbf{2}$ & -22 & 0 & -25 & -19 & -37 & -22 & -20.83 & -0.02 \\
\hline $\mathbf{3}$ & -25 & -2 & -35 & -28 & -52 & -32 & -29.00 & -0.03 \\
\hline $\mathbf{4}$ & -32 & -2 & -40 & -36 & -57 & -36 & -33.83 & -0.03 \\
\hline $\mathbf{5}$ & -38 & 0 & -43 & -43 & -63 & -41 & -38.00 & -0.04 \\
\hline $\mathbf{6}$ & -40 & -3 & -45 & -44 & -72 & -48 & -42.00 & -0.04 \\
\hline $\mathbf{7}$ & -43 & -5 & -48 & -45 & -77 & -49 & -44.50 & -0.04 \\
\hline $\mathbf{8}$ & -46 & -19 & -50 & -45 & -78 & -49 & -47.83 & -0.05 \\
\hline $\mathbf{9}$ & -55 & -16 & -48 & -43 & -79 & -44 & -47.50 & -0.05 \\
\hline $\mathbf{1 0}$ & -60 & -20 & -52 & -33 & -79 & -31 & -45.83 & -0.05 \\
\hline $\mathbf{1 1}$ & -61 & -26 & -51 & -24 & -75 & -17 & -42.33 & -0.04 \\
\hline $\mathbf{1 2}$ & -61 & -26 & -40 & -16 & -63 & 3 & -33.83 & -0.03 \\
\hline $\mathbf{1 3}$ & -61 & -16 & -33 & 1 & -58 & 24 & -23.83 & -0.02 \\
\hline $\mathbf{1 4}$ & -61 & -2 & -15 & 22 & -52 & 41 & -11.17 & -0.01 \\
\hline $\mathbf{1 5}$ & -58 & 12 & -12 & 39 & -47 & 53 & -2.17 & 0.00 \\
\hline $\mathbf{1 6}$ & -57 & 20 & -14 & 48 & -42 & 61 & 2.67 & 0.00 \\
\hline $\mathbf{1 7}$ & -47 & 25 & -25 & 50 & -47 & 61 & 2.83 & 0.00 \\
\hline $\mathbf{1 8}$ & -47 & 28 & -40 & 50 & -58 & 57 & -1.67 & 0.00 \\
\hline $\mathbf{1 9}$ & -45 & 30 & -50 & 40 & -67 & 47 & -7.50 & -0.01 \\
\hline $\mathbf{2 0}$ & -45 & 31 & -72 & 35 & -74 & 35 & -15.00 & -0.02 \\
\hline
\end{tabular}

Tabel 5 pengujian di atas dapat diambil rata-rata bahwa:

a. Pembebanan terhadap lintasan Bed (guideways) terjadi pada titik posisi 2-13, dimana penyimpangan yang terjadi lebih dari penyimpangan yang diizinkan $(0,01 \mathrm{~mm} / 500$ $\mathrm{mm})$, bila dihitung ada 11 titik posisi $(11 \times 25$ $\mathrm{mm}=275 \mathrm{~mm}$ ).

b. Secara umum dapat dikatakan lebih separoh dari panjang lintasan $(275 \mathrm{~mm} / 500 \mathrm{~mm})$.

Tabel 6. Hasil Pengujian pada Mesin bubut 3 (M17)

\begin{tabular}{|c|c|c|c|c|c|c|c|c|}
\hline $\begin{array}{c}\text { Posisi } \\
\text { Pengujia } \\
\begin{array}{c}\mathbf{n} \\
\mathbf{2 5} \mathbf{~ m m})\end{array}\end{array}$ & $\mathbf{1}$ & $\mathbf{2}$ & $\mathbf{3}$ & $\mathbf{4}$ & $\mathbf{5}$ & $\mathbf{6}$ & $\begin{array}{c}\text { Rata- } \\
\text { rata }\end{array}$ & $\mathbf{m m}$ \\
\hline $\mathbf{1}$ & 0 & -5 & -25 & -12 & -2 & -14 & -9.67 & -0.01 \\
\hline $\mathbf{2}$ & -1 & -5 & -34 & -9 & -5 & -21 & -12.50 & -0.01 \\
\hline $\mathbf{3}$ & -3 & -6 & -42 & -20 & -10 & -26 & -17.83 & -0.02 \\
\hline $\mathbf{4}$ & -3 & -6 & -48 & -23 & -14 & -30 & -20.67 & -0.02 \\
\hline $\mathbf{5}$ & -4 & -8 & -55 & -27 & -21 & -30 & -24.17 & -0.02 \\
\hline $\mathbf{6}$ & -4 & -10 & -69 & -27 & -24 & -37 & -28.50 & -0.03 \\
\hline $\mathbf{7}$ & -4 & -13 & -61 & -28 & -24 & -40 & -28.33 & -0.03 \\
\hline $\mathbf{8}$ & -4 & -15 & -57 & -25 & -23 & -40 & -27.33 & -0.03 \\
\hline $\mathbf{9}$ & -4 & -22 & -49 & -25 & -21 & -34 & -25.83 & -0.03 \\
\hline $\mathbf{1 0}$ & -14 & -28 & -42 & -24 & -15 & -20 & -23.83 & -0.02 \\
\hline $\mathbf{1 1}$ & -17 & -30 & -32 & -15 & -6 & -5 & -17.50 & -0.02 \\
\hline $\mathbf{1 2}$ & -24 & -37 & -27 & -8 & -3 & 15 & -14.00 & -0.01 \\
\hline $\mathbf{1 3}$ & -24 & -32 & -17 & 8 & 8 & 37 & -3.33 & 0.00 \\
\hline $\mathbf{1 4}$ & -23 & -45 & -15 & 30 & 13 & 56 & 2.67 & 0.00 \\
\hline $\mathbf{1 5}$ & -18 & -22 & -15 & 40 & 13 & 69 & 11.17 & 0.01 \\
\hline
\end{tabular}




\begin{tabular}{|c|c|c|c|c|c|c|c|c|}
$\mathbf{1 6}$ & -16 & 2 & -12 & 48 & 12 & 70 & 17.33 & 0.02 \\
\hline $\mathbf{1 7}$ & -13 & 16 & -17 & 45 & 9 & 64 & 17.33 & 0.02 \\
\hline $\mathbf{1 8}$ & -12 & 20 & -42 & 41 & -3 & 56 & 10.00 & 0.01 \\
\hline $\mathbf{1 9}$ & -11 & 21 & -54 & 17 & -10 & 47 & 1.67 & 0.00 \\
\hline $\mathbf{2 0}$ & -11 & 22 & -74 & 14 & -27 & 33 & -7.17 & -0.01 \\
\hline
\end{tabular}

Tabel 6 pada hasil pengujian diatas dapat diambil rata-rata bahwa:

a. Pembebanan terhadap lintasan Bed (guideways) terjadi pada titik posisi 3-11, dimana penyimpangan yang terjadi lebih dari penyimpangan yang diizinkan $(0,01 \mathrm{~mm})$, bila dihitung ada 8 titik posisi $(8 \times 25 \mathrm{~mm}=200$ $\mathrm{mm}$ )

b. Secara umum dapat dikatakan hampir separoh dari panjang lintasan $(200 \mathrm{~mm} / 500 \mathrm{~mm})$.

\section{Tabel 7. Hasil Pengujian pada Mesin bubut 4} (M18)

\begin{tabular}{|c|c|c|c|c|c|c|c|c|}
\hline \multirow{2}{*}{$\begin{array}{c}\text { Posisi } \\
\text { Pengujian } \\
(25 \mathrm{~mm})\end{array}$} & \multicolumn{8}{|c|}{ Simpangan $(\mu \mathrm{m})$} \\
\hline & 1 & 2 & 3 & 4 & 5 & 6 & $\begin{array}{l}\text { Rata- } \\
\text { Rata }\end{array}$ & $\mathbf{m m}$ \\
\hline 1 & 4 & -8 & -25 & -10 & -11 & -10 & -10.00 & -0.01 \\
\hline 2 & 3 & -13 & -39 & -17 & -28 & -46 & -23.33 & -0.02 \\
\hline 3 & -1 & -20 & -55 & -31 & -43 & -56 & -34.33 & -0.03 \\
\hline 4 & -6 & -27 & -67 & -35 & -55 & -60 & -41.67 & -0.04 \\
\hline 5 & -8 & -25 & -72 & -39 & -59 & -65 & -44.67 & -0.04 \\
\hline 6 & -9 & -24 & -75 & -44 & -60 & -72 & -47.33 & -0.05 \\
\hline 7 & -10 & -25 & -77 & -46 & -60 & -73 & -48.50 & -0.05 \\
\hline 8 & -13 & -24 & -80 & -45 & -60 & -71 & -48.83 & -0.05 \\
\hline 9 & -17 & -26 & -80 & -47 & -60 & -65 & -49.17 & -0.05 \\
\hline 10 & -22 & -29 & -80 & -43 & -60 & -56 & -48.33 & -0.05 \\
\hline 11 & -28 & -27 & -79 & -46 & -59 & -42 & -46.83 & -0.05 \\
\hline 12 & -32 & -22 & -73 & -29 & -50 & -32 & -39.67 & -0.04 \\
\hline 13 & -32 & -25 & -63 & -9 & -42 & -15 & -31.00 & -0.03 \\
\hline 14 & -29 & -17 & -52 & 4 & -35 & 7 & -20.33 & -0.02 \\
\hline 15 & -26 & -5 & -45 & 22 & -32 & 23 & -10.50 & -0.01 \\
\hline 16 & -24 & 2 & -43 & 25 & -33 & 28 & -7.50 & -0.01 \\
\hline 17 & -18 & 5 & -50 & 26 & -40 & 26 & -8.50 & -0.01 \\
\hline 18 & -15 & 7 & -63 & 24 & -45 & 15 & -12.83 & -0.01 \\
\hline 19 & -10 & 10 & -72 & 16 & -65 & 7 & -19.00 & -0.02 \\
\hline 20 & -10 & 10 & -88 & 11 & -66 & -1 & -24.00 & -0.02 \\
\hline
\end{tabular}

Tabel 7 pada hasil pengujian diatas dapat diambil rata-rata bahwa:

a. Pembebanan terhadap lintasan Bed (guideways) terjadi pada titik posisi 2-14, dimana penyimpangan yang terjadi lebih dari penyimpangan yang diizinkan $(0,01 \mathrm{~mm})$, bila dihitung ada 12 titik posisi $(12 \times 25 \mathrm{~mm}=300$ $\mathrm{mm}$ ).

b. Secara umum dapat dikatakan lebih separoh dari panjang lintasan $(300 \mathrm{~mm} / 500 \mathrm{~mm})$.

Tabel 8. Hasil Pengujian pada Mesin bubut 5 (M19)

\begin{tabular}{|c|c|c|c|c|c|c|c|c|}
\hline \multirow{2}{*}{$\begin{array}{c}\text { Posisi } \\
\text { Pengujian } \\
(25 \mathrm{~mm})\end{array}$} & \multicolumn{8}{|c|}{ Simpangan $(\mu \mathrm{m})$} \\
\hline & 1 & 2 & 3 & 4 & 5 & 6 & $\begin{array}{l}\text { Rata- } \\
\text { Rata }\end{array}$ & $\mathbf{m m}$ \\
\hline 1 & -5 & -3 & -28 & -3 & -7 & -7 & -8.83 & -0.01 \\
\hline 2 & -12 & -3 & -40 & -3 & -24 & -19 & -16.83 & -0.02 \\
\hline 3 & -20 & -4 & -43 & -5 & -25 & -22 & -19.83 & -0.02 \\
\hline 4 & -29 & -8 & -44 & -12 & -30 & -34 & -26.17 & -0.03 \\
\hline 5 & -29 & -8 & -42 & -18 & -38 & -46 & -30.17 & -0.03 \\
\hline 6 & -27 & -12 & -43 & -21 & -43 & -55 & -33.50 & -0.03 \\
\hline 7 & -27 & -16 & -43 & -22 & -43 & -57 & -34.67 & -0.03 \\
\hline 8 & -27 & -24 & -43 & -22 & -43 & -35 & -32.33 & -0.03 \\
\hline 9 & -27 & -30 & -45 & -10 & -43 & -21 & -29.33 & -0.03 \\
\hline 10 & -27 & -40 & -48 & 2 & -43 & -13 & -28.17 & -0.03 \\
\hline 11 & -27 & -40 & -55 & 8 & -42 & -4 & -26.67 & -0.03 \\
\hline 12 & -27 & -40 & -56 & 10 & -37 & 5 & -24.17 & -0.02 \\
\hline 13 & -27 & -35 & -48 & 20 & -37 & 10 & -19.50 & -0.02 \\
\hline 14 & -27 & -14 & -41 & 27 & -37 & 25 & -11.17 & -0.01 \\
\hline 15 & -27 & 5 & -38 & 33 & -37 & 35 & -4.83 & 0.00 \\
\hline 16 & -26 & 20 & -38 & 44 & -36 & 39 & 0.50 & 0.00 \\
\hline 17 & -25 & 26 & -44 & 46 & -38 & 40 & 0.83 & 0.00 \\
\hline 18 & -22 & 29 & -52 & 46 & -40 & 36 & -0.50 & 0.00 \\
\hline 19 & -22 & 31 & -60 & 46 & -46 & 35 & -2.67 & 0.00 \\
\hline 20 & -22 & 33 & -69 & 37 & -48 & 30 & -6.50 & -0.01 \\
\hline
\end{tabular}

Tabel 8 pada hasil pengujian diatas dapat diambil rata-rata bahwa:

a. Pembebanan terhadap lintasan Bed (guideways) terjadi pada titik posisi 2-13, dimana penyimpangan yang terjadi lebih dari penyimpangan yang diizinkan $(0,01 \mathrm{~mm})$, bila dihitung ada 11 titik posisi $(11 \times 25 \mathrm{~mm}=275$ $\mathrm{mm})$.

b. Secara umum dapat dikatakan lebih separoh dari panjang lintasan $(275 \mathrm{~mm} / 500 \mathrm{~mm})$.

\section{Tabel 9. Hasil Pengujian pada Mesin bubut 6} (M20)

\begin{tabular}{|c|c|c|c|c|c|c|c|c|}
\hline Posisi & \multicolumn{7}{|c|}{ Simpangan $(\boldsymbol{\mu m})$} \\
\cline { 2 - 9 } $\begin{array}{c}\text { Pengujian } \\
(\mathbf{2 5} \mathbf{~ m m})\end{array}$ & $\mathbf{1}$ & $\mathbf{2}$ & $\mathbf{3}$ & $\mathbf{4}$ & $\mathbf{5}$ & $\mathbf{6}$ & $\begin{array}{c}\text { Rata- } \\
\text { Rata }\end{array}$ & $\mathbf{m m}$ \\
\hline $\mathbf{1}$ & -5 & -2 & -76 & -25 & -21 & -15 & -24.00 & -0.02 \\
\hline $\mathbf{2}$ & -9 & -5 & -93 & -31 & -34 & -27 & -33.17 & -0.03 \\
\hline $\mathbf{3}$ & -10 & -8 & -102 & -39 & -45 & -33 & -39.50 & -0.04 \\
\hline $\mathbf{4}$ & -10 & -11 & -111 & -39 & -46 & -42 & -43.17 & -0.04 \\
\hline
\end{tabular}




\begin{tabular}{|c|c|c|c|c|c|c|c|c|}
\hline \multirow{2}{*}{$\begin{array}{c}\text { Posisi } \\
\text { Pengujian } \\
(25 \mathrm{~mm})\end{array}$} & \multicolumn{8}{|c|}{ Simpangan $(\mu \mathrm{m})$} \\
\hline & 1 & 2 & 3 & 4 & 5 & 6 & $\begin{array}{c}\text { Rata- } \\
\text { Rata }\end{array}$ & $\mathbf{m m}$ \\
\hline 5 & -10 & -12 & -115 & -46 & -46 & -46 & -45.83 & -0.05 \\
\hline 6 & 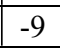 & -15 & -110 & -46 & -46 & -48 & -45.67 & -0.05 \\
\hline 7 & -9 & -18 & -115 & -48 & -46 & -55 & -48.50 & -0.05 \\
\hline 8 & -9 & -19 & 118 & -48 & -46 & -55 & -49 & -0.05 \\
\hline 9 & -10 & -26 & -110 & -45 & -46 & -43 & -46.67 & -0.05 \\
\hline 10 & -16 & -37 & -108 & -44 & -45 & -33 & -47.17 & -0.05 \\
\hline 11 & -22 & -39 & -113 & -45 & -41 & -25 & -47.50 & -0.05 \\
\hline 12 & -23 & -39 & -107 & -30 & -28 & -2 & -38.17 & -0.04 \\
\hline 13 & -23 & -36 & -85 & -15 & -15 & - & -26.17 & -0.03 \\
\hline 14 & -20 & -27 & -72 & -2 & -10 & 50 & -13.50 & -0.01 \\
\hline 15 & -16 & -18 & -69 & 31 & -12 & 78 & -1.00 & 000 \\
\hline 16 & -11 & -16 & -70 & 35 & -18 & 88 & 1.33 & .00 \\
\hline 17 & -2 & -14 & -85 & 30 & -39 & 84 & \begin{tabular}{|l|}
-4.33 \\
\end{tabular} & 0.00 \\
\hline 18 & -1 & -13 & -100 & 24 & -53 & 73 & -11.67 & -0.01 \\
\hline 19 & -1 & -11 & -115 & 13 & -64 & 59 & -19.83 & -0.02 \\
\hline 20 & -1 & -10 & -135 & 0 & -76 & 41 & -30.17 & -0.03 \\
\hline
\end{tabular}

Tabel 9 pada hasil pengujian serta grafik diatas dapat diambil bahwa:

a. Pembebanan terhadap lintasan Bed (guideways) terjadi pada titik posisi 1-13, dimana penyimpangan yang terjadi lebih dari penyimpangan yang diizinkan $(0,01 \mathrm{~mm})$, bila dihitung ada 13 titik posisi $(13 \times 25 \mathrm{~mm}=325$ $\mathrm{mm})$.

b. Secara umum dapat dikatakan lebih separoh dari panjang lintasan $(325 \mathrm{~mm} / 500 \mathrm{~mm})$.

Dapat disimpulkan pada Pengujian Pembimbing jalan Kepala lepas (Tailstock Guideways) terhadap Gerakan Eretan (Carriage) bahwa:

a. Jarak Penyimpangan toleransi minimum ada pada Mesin bubut (M17) yaitu sekitar 200 $\mathrm{mm} / 500 \mathrm{~mm}$ panjang lintasan.

b. Untuk Jarak penyimpangan toleransi yang paling maximum ada pada Mesin bubut (M20) yaitu sekitar $325 \mathrm{~mm} / 500 \mathrm{~mm}$ panjang lintasan.

Setelah dilakukannya semua pengujian terhadap ke-6 unit Objek penelitian (Mesin bubut Maximat Super 11), maka ditarik kesimpulan bahwa mesin bubut M17 (Toleransi Mininum) dan mesin bubut M20 (Toleransi Maximum) yang dipakai dalam pengujian terhadap benda kerja dalam pembubutan rata.

\section{c. Pengujian Dinamik Benda kerja (Pembubutan rata) \\ 1) Benda kerja (M17)}

Tabel 10. Kebulatan Benda kerja (M17)

\begin{tabular}{|c|c|c|c|c|}
\hline \multirow{2}{*}{ Titik Pengujian } & \multicolumn{4}{|c|}{ Posisi Pengujian (mm) } \\
\cline { 2 - 5 } & $\mathbf{A}$ & $\mathbf{B}$ & $\mathbf{C}$ & $\mathbf{D}$ \\
\hline $\mathbf{1}$ & 0 & 0 & 0 & 0 \\
\hline $\mathbf{2}$ & -0.001 & 0 & 0 & 0 \\
\hline $\mathbf{3}$ & -0.001 & 0 & 0 & 0 \\
\hline $\mathbf{4}$ & -0.001 & 0 & 0 & 0 \\
\hline $\mathbf{5}$ & -0.001 & 0 & 0 & 0 \\
\hline $\mathbf{6}$ & -0.003 & 0 & 0 & 0 \\
\hline $\mathbf{7}$ & -0.005 & 0 & 0 & 0 \\
\hline $\mathbf{8}$ & -0.005 & 0 & 0 & 0 \\
\hline $\mathbf{9}$ & -0.005 & 0 & 0 & 0 \\
\hline $\mathbf{1 0}$ & -0.005 & 0 & 0 & 0 \\
\hline $\mathbf{1 1}$ & -0.003 & 0 & 0 & 0 \\
\hline $\mathbf{1 2}$ & -0.003 & 0 & 0.01 & 0 \\
\hline $\mathbf{1 3}$ & -0.002 & -0.01 & 0.01 & 0 \\
\hline $\mathbf{1 4}$ & -0.006 & -0.01 & 0.01 & 0 \\
\hline $\mathbf{1 5}$ & -0.003 & -0.01 & 0.01 & 0 \\
\hline $\mathbf{1 6}$ & 0 & 0 & 0 & 0 \\
\hline Rata-rata & $\mathbf{- 0 . 0 0 2 8}$ & $\mathbf{- 0 . 0 0 1 9}$ & $\mathbf{0 . 0 0 3}$ & $\mathbf{0}$ \\
\hline
\end{tabular}

Secara umum dari pengujian kebulatan benda kerja (M17) bisa dilihat dari data tabel diatas bahwanya rerata disetiap bagian pengujian masih dalam batas toleransi yang telah ditetapkan $\mathbf{( 0 . 0 1 5}$ $\mathbf{m m} / \mathbf{1 2 0} \mathbf{~ m m}$ ).

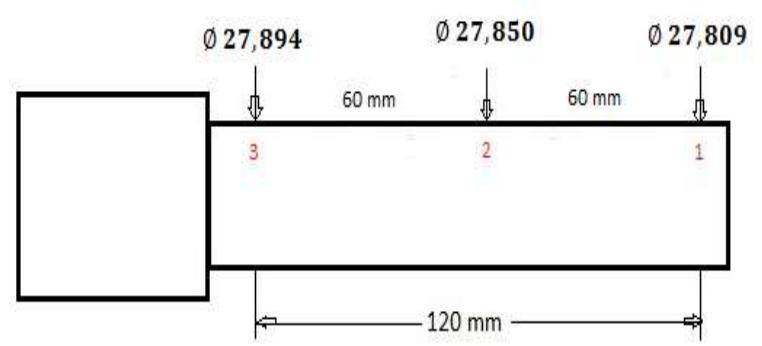

\section{Gambar 13. Hasil Pengukuran Diameter Benda kerja (M17)}

Hasil pengukuran diameter pada benda kerja (M17) seperti pada gambar diatas dari titik 1 menuju titik 3 mengalami kenaikan sekitar $\varnothing 0,085$ $\mathrm{mm}$, jika dianalisa pada posisi 3 yang dekat dengan spindle mengalami penurunan terhadap kearah posisi 1 .

\section{2) Benda kerja (M20)}

Tabel 11. Kebulatan Benda kerja (M20)

\begin{tabular}{|c|c|c|c|c|}
\hline \multirow{2}{*}{ Titik Pengujian } & \multicolumn{5}{|c|}{ Posisi Pengujian } \\
\cline { 2 - 5 } & A & B & C & D \\
\hline $\mathbf{1}$ & 0 & 0 & 0 & 0 \\
\hline $\mathbf{2}$ & 0 & 0 & -0.01 & -0.008 \\
\hline $\mathbf{3}$ & 0 & 0 & -0.016 & -0.009 \\
\hline $\mathbf{4}$ & 0 & 0 & -0.025 & -0.014 \\
\hline
\end{tabular}




\begin{tabular}{|c|c|c|c|c|}
$\mathbf{5}$ & 0 & 0.01 & -0.025 & -0.022 \\
\hline $\mathbf{6}$ & 0 & 0.01 & -0.011 & -0.027 \\
\hline $\mathbf{7}$ & 0 & 0.013 & -0.01 & -0.027 \\
\hline $\mathbf{8}$ & 0 & 0.017 & -0.01 & -0.026 \\
\hline $\mathbf{9}$ & 0 & 0.011 & -0.008 & -0.02 \\
\hline $\mathbf{1 0}$ & 0 & 0.011 & -0.008 & -0.021 \\
\hline $\mathbf{1 1}$ & 0.01 & 0.011 & -0.005 & 0.015 \\
\hline $\mathbf{1 2}$ & 0.01 & 0.01 & -0.004 & -0.01 \\
\hline $\mathbf{1 3}$ & 0.008 & 0.008 & -0.004 & -0.009 \\
\hline $\mathbf{1 4}$ & 0.009 & 0.007 & -0.002 & 0.006 \\
\hline $\mathbf{1 5}$ & 0.004 & 0.004 & -0.003 & -0.002 \\
\hline $\mathbf{1 6}$ & 0 & 0 & 0 & 0 \\
\hline Rata-rata & $\mathbf{0 . 0 0 2 6}$ & $\mathbf{0 . 0 0 7}$ & $\mathbf{- 0 . 0 0 9}$ & $\mathbf{- 0 . 0 1 1}$ \\
\hline
\end{tabular}

Secara umum dari pengujian kebulatan benda kerja (M20) bisa dilihat dari data tabel diatas bahwanya rerata disetiap bagian pengujian masih dalam batas toleransi yang telah ditetapkan (0.015 $\mathbf{m m} / \mathbf{1 2 0} \mathbf{~ m m}$ ).

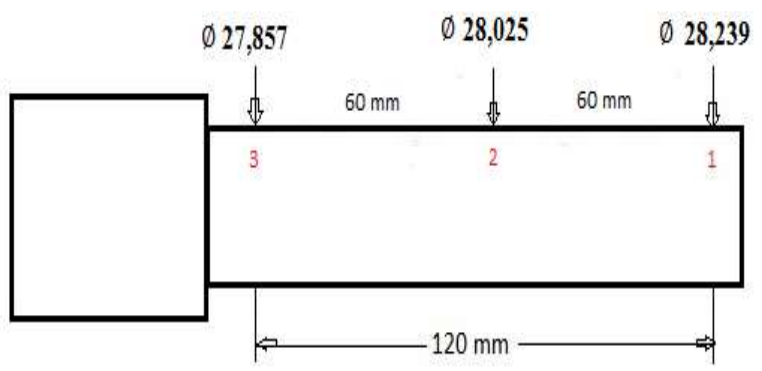

\section{Gambar 14. Hasil Pengukuran Diameter Benda kerja (M20)}

Hasil pengukuran diameter Pada benda kerja (M20) seperti pada gambar diatas dari titik 1 menuju titik 3 mengalami penurunan sekitar $\emptyset 0,628$, jika dianalisa pada posisi 3 yang dekat dengan spindle mengalami kenaikan terhadap kearah posisi 1 .

Tabel 12. Perbandingan Rata-rata kebulatan antara benda kerja (M17-M20)

\begin{tabular}{|c|c|c|c|c|c|c|}
\hline \multirow{2}{*}{ No } & \multirow{2}{*}{$\begin{array}{l}\text { No. } \\
\text { Mesin }\end{array}$} & \multicolumn{4}{|c|}{ Posisi } & \multirow{2}{*}{$\begin{array}{c}\text { Standar } \\
\text { yang } \\
\text { diizinkan }\end{array}$} \\
\hline & & 1 & 2 & 3 & 4 & \\
\hline 1 & M17 & $\mid-0.0028$ & -0.0019 & 0.003 & $\mathbf{0}$ & $0.015 \mathrm{~mm}$ \\
\hline 2 & M20 & 0.0026 & 0.007 & -0.009 & -0.011 & sda \\
\hline
\end{tabular}

\section{KESIMPULAN}

Hasil pengujian ketelitian geometri Mesin bubut Maximat Super 11 dapat disimpulkan Pengujian Run Out Spindle Nose posisi a dan b, hasil pengujian yang dicapai masih dalam batas toleransi dimana standar yang diizinkan menurut
Schlesinger standard pada pengujian ini adalah $0.01 \mathrm{~mm}$. Jadi bisa dikatakan dalam pengujian ini masih layak karena masuk dalam batas toleransi yang diizinkan. Pengujian Ketirusan dari Lubang Spindle Nose, hasil pengujian yang dicapai pada ke 6 unit mesin tersebut semuanya sudah melewati batas toleransi yang diizinkan $(0.01 \mathrm{~mm}-0.02 \mathrm{~mm} / 300 \mathrm{~mm})$. Pengujian pembimbing jalan Kepala lepas (Tailstock Guideways) terhadap Gerakan Eretan (Carriage), hasil yang dicapai dari pengujian tersebut dapat disimpulkan dari ke 6 unit mesin yang diteliti semua mengalami penyimpangan dari batas yang diizinkan $(0.01 \mathrm{~mm} / 500 \mathrm{~mm})$, dimana kebanyakan lebih dari separoh panjang lintasan mengalami keausan/pengerusan bidang.

Pengujian kebulatan benda kerja (M17 dan M20) disimpulkan bahwa masih dalam batas toleransi yang diizinkan $(0.01 \mathrm{~mm}$ per $120 \mathrm{~mm})$, namun untuk karakteristik geometri kedua benda kerja tersebut tidak masuk kriteria secara bentuk dan ukuran geometri.

\section{DAfTar Pustaka}

[1] Schlesinger (1977). Testing Machine Tools (Seventh Edition). Plant Engineering Department: India.

[2] Wirawan, Sumbodo dkk. 2008. Teknik Produksi Mesin Industri (Jilid 2). Departemen Pendidikan Nasional: Jakarta.

[3] A, Y., Indrawan, E., Helmi, N., Aziz, A., \& Putra, Y. (2019). Pengaruh Sudut Potong dan Kecepatan Putaran Spindel Terhadap Kekasaran Permukaan pada Proses Bubut Mild Steel ST 37. INVOTEK: Jurnal Inovasi Vokasional Dan Teknologi, 19(2), 29-36.

https://doi.org/https://doi.org/10.24036/invotek.v1 9i2.582.

[4] Indrawan, E., \& Rifelino, R. (2014). PENINGKATAN AKTIFITAS BELAJAR MAHASISWA MELALUI PENGGUNAAN MULTIMEDIA DALAM MATA KULIAH METROLOGI INDUSTRI. Penelitian Pendidikan, $5(1)$.

[5] Alan S. Morris (2001). Measurement \& instrumentation principles. ButterworthHeinemann: Oxford.

[6] Suarman Makhzu (2013). Teknologi Pemesinan. FT-UNP Padang. 


\section{Biodata Penulis}

Eko Indrawan, lahir di Pulau Kijang, 14 Januari 1980. Sarjana di Jurusan Teknik Mesin ITP Padang Tahun 1999-2003. Tahun 2008 memperoleh gelar Magister Pendidikan di jurusan Teknologi Pendidikan Program Pascasarjana UNP

dengan bidang konsentrasi Pendidikan Kejuruan. Staf pengajar di jurusan Teknik Mesin FT UNP sejak tahun 2010-sekarang.

Yufrizal A, lahir di Padang, 21 April 1961.Sarjana Pendidikan di Jurusan Teknik Mesin FPTK 19811985. Tahun 2012 memperoleh gelar Magister Pendidikan di jurusan Teknologi Pendidikan Program Pascasarjana UNP dengan bidang konsentrasi Pendidikan Kejuruan. Staf pengajar di jurusan Teknik Mesin FT UNP sejak tahun 1986sekarang.

Abdul Aziz, lahir di Kodya Padang, 04 Maret 1962. Sarjana Pendidikan di Jurusan Teknik Mesin FPTK 1981-1985. Tahun 2010 memperoleh gelar Magister Pendidikan di jurusan Teknologi Pendidikan Program Pascasarjana UNP dengan bidang konsentrasi Pendidikan Kejuruan. Staf pengajar di jurusan Teknik Mesin FT UNP sejak tahun 1986-sekarang.

Rifelino, lahir di Jakarta, 15 Februari 1980. Sarjana Pendidikan di Jurusan Teknik Mesin FT 20002005. Tahun 2012 memperoleh gelar Magister Teknik di Program Pascasarjana Institut Teknologi Sepeluh Nopember, Surabaya dengan bidang Sistem Manufaktur. Staf pengajar di jurusan Teknik Mesin FT UNP sejak tahun 2006-sekarang.

Muhammad Iqbal Tawakal, Sarjana Pendidikan di Jurusan Teknik Mesin FT 2011-2015 
